\title{
Phytoremediation Of Crude Oil Impacted Soil Using Purple Nutsedge
}

\section{*NWAICHI, EO; CHUKWUERE, CO; ABOSI, PJ; ONUKWURU, GI}

\author{
Department of Biochemistry, University of Port Harcourt, Rivers State Nigeria \\ *Corresponding AuthorEmail:nodullm@yahoo.com
}

\begin{abstract}
The present study investigated the viability of purple nutsedge in the phytoremediation of a crude oilcontaminated land in the Kom-Kom community, Oyigbo, Rivers state, Nigeria. 150g of soil samples were randomly collected from two (2) different points on the polluted site and a control site and analyzed for Petroleum Aromatic Hydrocarbons (PAHs), Total Petroleum Hydrocarbons (TPH) and Heavy metals ( $\mathrm{Pb}, \mathrm{Cd}, \mathrm{Cr} \& \mathrm{Ni}$ ). in soils and plants before and after phytoremediation. Plants were transplanted into the contaminated and contaminated soil after soil sample collection.After planting,the progress of plant growth was observed and recorded biweekly for 3 months before harvesting. From the results obtained, over $80 \%$ and $66 \%$ PAHs and TPHs phytodegradation efficiencies were achieved using the plant while $\mathrm{Cd}, \mathrm{Pb}$ and $\mathrm{Cr}$ were removed by $90 \%, 67 \%$ and $39.2 \%$ respectively. The Bioaccumulation Factor (B.F) of the heavy metals in study plant were found to be greated than 1 which makes it suitable for phytoextraction of heavy metals. Therefore, the study suggests that purple nutsedge can be useful in the phytoremediation of a crudeoil polluted soil.
\end{abstract}

\section{DOI: $\underline{\text { https://dx.doi.org/10.4314/jasem.v25i3.25 }}$}

Copyright: Copyright (C) 2021 Nwaichi, et al.. This is an open access article distributed under the Creative Commons Attribution License (CCL), which permits unrestricted use, distribution, and reproduction in any medium, provided the original work is properly cited.

Dates: Received: 12 December 2020; Revised: 26 January 2021; Accepted: 12 February 2021

Keywords: Hydrocarbons, Heavy metals, Phytoremediation, Crude oil, Purple nutsedge

The discovery of crude oil in Nigeria has significantly improved her economy due to its importance as a significant source of foreign exchange and in boosting the Gross domestic product (GDP) of the country. However, it's exploration and exploitation has posed immense danger and harm to the oil-producing communities due to the resultant effect it has on the aquatic life and soil topography of the oil-rich region. The Niger Delta region of Nigeria is well-known for the production of oil that commenced as far back as 1956 and the discovery of oil in the Niger Delta region improved the financial state of the economy but was immediately accompanied by a series of crude oil spillage on land and water giving rise to soil and water pollution (Adekunle et al., 2015). The major cause of oil spills has been identified to be from vandalization and leakages of pipelines. The effects of environmental pollution resulting from the production of oil became a topical issue at both national and international levels (Adekunle et al., 2015). Oil spillage results in contamination of the environment with aliphatic and aromatic hydrocarbons(such as Total Petroleum Hydrocarbon (TPH) \& Polycyclic Aromatic hydrocarbon (PAH) ) as well as heavy metals(such as $\mathrm{Pb}, \mathrm{Ni}, \mathrm{Cr} \& \mathrm{Cd}$ ). Hence, it is essential to develop efficient remediation strategies to reduce the disastrous effect of hydrocarbon and heavy metals pollution in soils in the Niger Delta Region as, high concentrations in soils pose a great risk to humans and the entire ecosystem at large(Nwaichi, 2014; Nwaich et al., 2016). Also, it is pertinent to investigate methods and strategies to clean up oil spillage and prevent its disastrous effect on soil, animals, and humans. One of the most promising biological approaches, to deal with the problem of oil spillage is phytoremediation- which is an In-situ type of bioremediation, and the advantage of this approach over others is that it is cost-effective, eco-friendly, and suitable for the treatment of large volumes of soils in contaminated sites (Sabo et al., 2018). The four distinct mechanisms of phytoremediation include phytostabilization, phytodegradation, phytovolatilization, and rhizodegradation (Germida et al., 2002). Uptake of organic pollutants by plants is dependent on two major factors namely: abiotic (such as physiochemical properties of the molecule in terms of log octanol /water partition coeffiecient $\left\{\mathrm{K}_{\mathrm{ow}}\right\}$, its molecular weight and the composition of clays, iron oxides and organic oxides present in the soil) and biotic factors (such as transpiration rates, types of amount of lipids in root cells, enzyme complement, root exudates, and growth dilution) (Collins et al., 2006; Osuoha and Nwaichi, 2020)). From recent studies, it has been observed that uptake of PAHs by plants occurs primarily through the roots and secondarily through the leaves while the uptake of metals by plants occurs majorly through the process of phytoextraction. Phytoextraction is the process of 
removal of heavy metals from contaminated sites through their uptake into different parts of the plant (Suman et al.,2018). Cyperus rotundus (also known as purple nutsedge) is one of the dominant plant species found growing along the contaminated site and is tolerant to the soil and weather conditions of the contaminated area. In previous field researches and investigations, it has been found that Cyperus rotundus can be beneficial to the phytoremediation of oily soils due to its great root surface area (Wang et al., 2010). However, the study about the viability of of purple nutsedge to phytoremediate a crude oil impacted soil within oil-producing communities in Niger Delta rarely exist. This research aims to evaluate the viability of purple nutsedge to phytoremediate a crude oil impacted soil in Kom-Kom community, Oyibo Rivers state Nigeria.

\section{MATERIALS AND METHODS}

Description of the study area: The study area is located in Kom-Kom community, Oyigbo, Rivers state, Nigeria. The Trans Delta Bonny Light Line of an oil compan y passes through the area. A one-week crude oil spillage was reported in this community in March 2014. Reports showed that the cause of the release was from the vandalism of old above ground pipelines. The type of soil found in the study area is loamy soil and the most common type of weed found growing on the soil is Cyperus rotundus. It is important to mention that Kom-Kom Community is a fast-growing urban settlement and therefore needs environmental cleanup. Control soil consisted in a soil from same geographical location but with no history of crude oil pollution for comparison.

Sample collection: The samples used in the analysis of the project were collected from Kom-Kom community in Oyigbo, Rivers state. A hand soil auger was used to collect soil samples in replicates of three at a $30 \mathrm{~cm}$ depth from the contaminated study area and these were bulked. The samples were immediately placed in a sterilized, air tight cellophane bags, labelled and stored at $4{ }^{\circ} \mathrm{C}$ prior to laboratory analysis. Soil samples were also obtained in replicate of three from the control site. Taxonomic classification of the experimental soil was loamy sand. Three replicate samples of the plant were collected from the study area. The samples were immediately placed in a sterilized, air tight cellophane bags, labelled and stored at $4^{\circ} \mathrm{C}$ prior to laboratory analysis. The plant was identified by a taxonomist in the department of Plant Biology and Biotechnology, University of Port Har court to be Cyperus rotundus (Purple nutsedge).

Methods: The study was an experiment carried out at the the contaminated site.Three 12L buckets were filled to the brim with uncontaminated soil for the control samples while three different points in the contaminated sites were mapped out for polluted samples.150g of Soil samples were gotten from the contaminated and uncontaminated soi 1 for laboratory analysis before planting. Plants were transplanted into the contaminated and contaminated soil after soil sample collection. After planting,the progress of plant height and width was observed and recorded biweekly for 3 months before harvesting. The position and terrain of the mapped out sites were the only notable differences between the polluted samples.All samples were prepared in triplicate determination.

Preparation of samples: Soil samples were air-dried under room temperature to ensure constant weight. After drying, they were homogenised to obtain finer texture and remove unwanted particles. The air-dried soil samples were then sieved through a $2 \mathrm{~mm}$ polythene sieve to obtain only partcles less than $2 \mathrm{~mm}$ mesh size. Plant samples were gently washed under running water, cut into smaller sizes using a knife and oven dried at $60^{\circ} \mathrm{C}$ for 24 hours to ensure constant weight. The dried samples were then homogenized to a suitable size for digestion and analysis.

\section{Samples digestion and analysis}

PAH AND TPH: Ten grams (10g) of the sample was measured into a solvent rinsed beaker. Thirty (30) $\mathrm{ml}$ of dichloromethane was then added to the sample. Sample was then spiked with ortho-terphenyl. Sample was shaken in a vortex mixture for five minutes. Sample was placed in an orbital shaker for thirty minutes. The extract was filtered through a glass funnel with glass wool and anhydrous sodium sulphate. The extract was then transferred to a Teflon lined screw cap vial ready for PAH and TPH subsid ized using a gas chromatography. The extract was then analyzed using gas chromatography.

Heavy metals: $0.2 \mathrm{~g}$ of sample was dissolved in $6 \mathrm{ml}$ of concentrated nitric acid (HNO3), $2 \mathrm{ml}$ of concentrated hydrochloric acid $(\mathrm{HCl})$ and $2 \mathrm{ml}$ of hydrofluoric acid (HF) and set on a water bath to dissolve completely. The concentrations of the heavy metals $\mathrm{Cd}, \mathrm{Cr}, \mathrm{Ni}$, and $\mathrm{Pb}$ in the solution were analyzed with Atomic Absorption Spectrometer (AAS).

Nitrate: About $5 \mathrm{~g}$ of soil sample was weighed and $20 \mathrm{ml}$ of sodium acetate extracting solution added and shaken for 1 minute and filtered with Whatmann filter paper. About $5 \mathrm{ml}$ of filterate was added to Nitraver 5 powder pillow, shaked for 1 minute and allowed to stand for 5 minutes. The absorbance was read using UV visible spectrophotometer.

Phosphate: An aliquote of $2 \mathrm{~g}$ of soil sample was weighed, $40 \mathrm{ml}$ extracting solution was added and filtered. About $5 \mathrm{ml}$ of soil extract was added and $25 \mathrm{ml}$ 
of distilled water. It was left for 10 mins and the absorbance was read.

Electrical Conductivicty:The conductivicty meter was calibrated using the $1000 \mathrm{uS} / \mathrm{cm}$ conductivicty standard. The electron was rinsed with de-ionized water. $10 \mathrm{~g}$ of dried sample was weighed and added into $10 \mathrm{ml}$ of deionized water. It was shaken for 10 minutes and then the conductivicty value was taken when the reading was stable.

Formulas for hydrocarbon and heavy metal remediation

Amount Remediated $\left(\mathrm{AR}_{(\text {Parameter })}\right)=$ Initial Conc. (Ic) - Final Conc. (Fc)

$\%$ Bioremediation $=\frac{A R}{I c} \times 100$

Bioaccumulation Factor $($ B.F $)=\frac{[C p]}{[C s]}$

Where $[\mathrm{Cp}]$ means metal Conc. in Plant Tissue (whole plant) and [Cs] means initial Conc. of Metal in Substrate i.e soil

Data analysis: Statistical analysis was performed using statistical packages for social sciences (version 20). Result were expressed as mean \pm standard deviation of triplicate determination. The data were by one way ANOVA followed by Duncan's multiple range test, to determine the level of significance expressed at $95 \%$ confidence level $(\mathrm{p} \leq 0.05)$.

\section{RESULTS AND DISCUSSION}

Petroleum hydrocarbons and heavy metals are accumulated in soils as a result of oil spillage. Results of Polycyclic Aromatic hydrocarbons(PAH) and Total Petroleum Hydrocarbons (TPH) in soil samples and Heavy metals $(\mathrm{Pb}, \mathrm{Ni}, \mathrm{Cr}, \mathrm{Cd})$ found in soil and plant samples are presented in Tables $1,2 \& 3$. There is an increasing problem of crude oil pollution which has affected several oil producing countries especially Nigeria. Crude oil contamination has negatively impacted plants and the ecosystem at large(Odukayo et al., 2019). Though crude oil contains majorly aliphatic and aromatic compunds, it also contains trace element like nickel, iron, aluminium and some heavy metals like lead, cadmium and chromium (Wilberforce, 2016). From Table 1, the PAHs and TPHs decreased significantly $(\mathrm{p}<0.05)$ after phytoremediation, giving a $80 \%$ and $66 \%$ reduction in concentrations of PAHs and TPHs respectively; this is in agreement with the study reported by Hovet et al. (2016). The decrease observed in the soil samples indicated that $C$. rotundus was effective in taking up the PAH into its system. Also,there was a significant difference between the contaminated and uncontaminated soil. High levels of PAHs and TPHs has a negative impact on the availability of nutients needed for plant growth and can lead to death of acquatic and terrestrial organisms.

Table 1:hydrocarbonscontent (PAH \& TPH) (mg/kg) of remedied and control soils

\begin{tabular}{lllll}
\hline Hydrocarbons & Initial sample & Final sample & Initial control & Final control \\
\hline PAH & $0.61 \pm 0.03$ & $0.12 \pm 0.01$ & $0.04 \pm 0.01$ & $0.01 \pm 0.00$ \\
TPH & $5726.34 \pm 90.00$ & $1963.00 \pm 10.00$ & $222.59 \pm 10.00$ & $7.84 \pm 0.10$ \\
\hline \multicolumn{2}{l}{ a are expressed as mean \pm standard deviations of triplicate determinations at a significant differen }
\end{tabular}
$\mathrm{p} \leq 0.05$.

Table 2: Heavy metals of ( $\mathrm{Pb}, \mathrm{Ni}, \mathrm{Cr} \& \mathrm{Cd}$ ) of remedied and control soils

\begin{tabular}{lllll}
\hline Heavy Metals & Initial sample & Final sample & Initial control & Final control \\
\hline Lead $(\mathrm{Pb})$ & $0.0450 \pm 0.0010$ & $0.0195 \pm 0.0170$ & $0.1200 \pm 0.0200$ & $0.0001 \pm 0.0000$ \\
\hline Nickel $(\mathrm{Ni})$ & $0.0001 \pm 0.0000^{*}$ & $0.0001 \pm 0.0000^{*}$ & $0.0001 \pm 0.0000^{*}$ & $0.0001 \pm 0.0000^{*}$ \\
\hline Chromium $(\mathrm{Cr})$ & $0.3750 \pm 0.1560$ & $0.2280 \pm 0.1370$ & $0.2820 \pm 0.0020$ & $0.0001 \pm 0.0000$ \\
\hline Cadmium $(\mathrm{Cd})$ & $0.0010 \pm 0.0000$ & $0.0001 \pm 0.0000$ & $0.0001 \pm 0.0000^{*}$ & $0.0001 \pm 0.0000^{*}$ \\
\hline
\end{tabular}

Data are expressed as mean \pm standard deviations of triplicate determinations. Values with the symbol * in the same row are not significantly different while others are significantly different at $p \leq 0.05$.

Table 3: Heavy metals $(\mathrm{Pb}, \mathrm{Ni}, \mathrm{Cr} \& \mathrm{Cd})$ of plants from remedied and control soils

\begin{tabular}{lllll}
\hline Plant & Lead(Pb) & Chromium(Cr) & Cadmium(Cd) & Nickel(Ni) \\
\hline Sample & $0.165 \pm 0.001^{*}$ & $0.55 \pm 0.01$ & $0.006 \pm 0.001$ & $0.0009 \pm 0.0001^{*}$ \\
Control & $0.183 \pm 0.001^{*}$ & $0.6 \pm 0.1$ & $0.005 \pm 0.001$ & $0.008 \pm 0.001^{*}$ \\
\hline
\end{tabular}

Data are expressed as mean \pm standard deviations of triplicate determinations.Values with the symbol $*$ in the same column are significantly different while others are not significantly different at $p \leq 0.05$

Table 2 shows the rate at which the level of the heavy metals was reduced in the contaminated soils. $\mathrm{Pb}, \mathrm{Cd}$ and $\mathrm{Cr}$ was significantly $(\mathrm{p}<0.05)$ reduced after phytoremediation while there was no significant $(\mathrm{p}<0.005)$ difference in $\mathrm{Ni}$ after phytoremediation. The Total Removal Percentage was calculated and it showed that $\mathrm{Cd}, \mathrm{Pb}$ and $\mathrm{Cr}$ were removed by $90 \%$,
$67 \%$ and $39.2 \%$ respectively while there was no removal of $\mathrm{Ni}$ from the polluted soil. This means that the plant is a good hyperaccumulator of $\mathrm{Pb}, \mathrm{Cd}, \mathrm{Ni}$ and $\mathrm{Cr}$ which is in line with the study of Messou et al., 2012. The bioaccumulation factor ( B.F) of the heavy metals in the analyzed plants gave a ratio greater than 1 which suggests that $C$. rotundus is suitable for 
phytoextraction of heavy metals. Since there was no significant decrease in the level of $\mathrm{Ni}$ in the soil after phytoremediation, further studies should be done to ascertain what factors could be responsible for these outcome. Heavy metals were found to be below the guideline levels (DPR, 2018). Heavy metals exert toxic effects to soil by reducing the activicty of soil microorganisms and inhibiting the physiological metabolism of plant even in low quantities (Singh and Kalamdhad, 2011). Accumulation of heavy metals along the food chain can have a deleterious effect on the health of humans and animals. Absorption and accumulation of heavy metals by plants is dependent on factors such as $\mathrm{pH}$, moisture and availability of nutrient.Toxicity and phytotoxicity of heavy metals to plants leads to chlorosis, weak growth and reduced nutrient uptake.

The physical examination conducted on the soil showed that the taxonomic classification of the soil was loamy sand. Analytical results showed that the soil was slightly acidic with a mean value $\mathrm{pH}$ of (6.4, \& 4.6 ) for experimental and control soil respectively which was found to be significantly different $(p<0.05)$. The presence of trees which caused the littering of leaves could be responsible for the lower $\mathrm{pH}$ of the control soil which is in line with the study of Vinje (2018). Soil pH plays an important role in the adsorption of heavy metals and controls the hydrolysis and solubility of metal hydroxide,carbonate and phosphates( Tokalioglu et al., 2006). The Electrical conductivity(EC) of the soil had mean values of $264 \mu \mathrm{S} / \mathrm{cm}$ and $209 \mu \mathrm{S} / \mathrm{cm}$ for experimental and control soils respectively and no $\operatorname{significant}(\mathrm{p}<0.05)$ difference was observed before and after phytoremediation. EC does not directly affect plant growth but can be used to indicate the amount of nutrients available for uptake by plants and the salinity levels of soils which can impede growth and microbial activicty (USDA, 2011). Macro nutrients such as Nitrogen, Potassium and Phosphorus are necessary for plant growth and were found to be below the soil agricultural standards (HSE-ENV, 2004). The nutrients in the soil (Nitrates \& Phosphates) were also seen to be affected by the phytoremediation process. The level of nitrates of experimental soil significantly $(\mathrm{p}<0.05)$ increased from $5.44 \mathrm{mg} / \mathrm{kg}$ to $16.01 \mathrm{mg} / \mathrm{kg}$ mean values after the phytoremediation process which is important for the uptake of other positive ions such as magnesium and calcium. However, the levels of phosphates dropped drastically from $13.31 \mathrm{mg} / \mathrm{kg}$ to $6.5 \mathrm{mg} / \mathrm{kg}$ mean values after the phytoremediation. No significant difference $(\mathrm{p}<0.05)$ was observed in the control soil before and after phytoremediation. The slopy terrain of the area could have resulted to the loss of phosphates through erosion and run-off as explained by USDA (2011). Potassium of the soil had mean values of $3.982 \mathrm{mg} / \mathrm{kg}$ and $1.287 \mathrm{mg} / \mathrm{kg}$ for experimental and control soils respectively and no significant $(\mathrm{p}<0.05)$ difference was observed after phytoremediation. Potassium is essential for the regulation of $\mathrm{CO}_{2}$ itake by plants.

Phytoremediation efficiency of Cyperus rotundus: In the phytoremediation of a crude oil impacted soil, the optimal growth of the plant is important (Anyasi et al.,2018; Nwaichi and Chuku, 2018). However, before the optimal growth of the plant in the contaminated soil, it must be able to withstand the phytotoxic effects of the contamination (Anyasi and Atagana 2014; Tanhan et al. 2011). The toxic nature of the hydrocarbons is due to their volatility and hydrophobicity and this leads to low aeration and water infiltration which is needed for optimal growth of plants (Anyasi et al.,2018). The rate of growth of purple nutsedge at the contaminated site was high. This shows that the plant was able to withstand the toxic nature of the hydrocarbons found in the soil. However, it was observed that there was reduction in the height and root length of plants in contaminated samples after harvesting as compared to the control sample which corresponds to the findings made by Basumatary et al. (2013). Exposure to heavy metals can have an adverse effect on the growth of plants . Cd is the most toxic heavy metals for plants and can inhibit plant growth and reduce crop yield. Decolouration in leaves' color can be associated with the presence of $\mathrm{Cd}$ which decreased the content of chlorophyll and carotenoids and increased nonphytochemical quenching as evidienced in the study of Garba et. al. (2018).

Conclusion: This study involved the evaluation of the viability of purple nutsedge to phytoremediate a hydrocarbon impacted soil. Purple nutsedge showed an ability to thrive in a hydrocarbon impacted soil and demonstrated good potentials for the phytoremediation of polycyclic aromatic hydrocarbons, and total petroleum hydrocarbon, and heavy metals like cadmium and lead. Obtained high bioaccumulation factor for studied heavy metals in purple nutsedge and the high hydrocarbons degradation efficiencies make it a suitable plant for such phytoremediation.

\section{REFERENCES}

Adekunle, IM; Osayande, M; Alawode, TT (2015). Biodegradation of Petroleum-Polluted Soils Using CNB-Tech- The Nigerian Experience. In: Biodegradation and Bioremediation of Polluted Systems- New Advances and Technologies. Retrieved from https://doi.org/ 10.5772/62116 
Anyasi, RO; Atagana, HI (2014). Enhancing growth performances of Chromolaena odorata in two soil samples by using cow manure as amendment. Pak $\mathbf{J}$ Bot. 46(5):1771-9.

Anyasi, RO; Atagana, HI (2018). Profiling of plants at petroleum contaminated site for phytoremediation. Int. J. Phytorem, 20(4): 352-361.

Collins, C; Martin, I; Fryer, M; (2006). Evaluation of Models for Predicting Plant Uptake of Chemicals from Soil. (Science Report-SC050021/SR), Environment Agency, Bristol.

Germida, JJ; Frick, CM; Farrell, RE; (2002) "Phytoremediation of oil-contaminated soils," in Soil Mineral-Organic Matter-Microorganism Interactions and Ecosystem Health. Ecological Significance of the Interactions among Clay Minerals, Organic Matter and Soil Biota, Vol. 28b: pp 169-186.

Nwaichi, EO; (2014) Environmental Impacts and Prospects of Petroleum Production: A Case Study of the Niger Delta. In: Daniels, J.A., Eds., Advances in Environmental Research, Vol. 35, Chapter 7, Nova Science Publishers Inc., New York: pp 173-188.

Nwaichi, EO; Chuku, LC; Ighoavwogan, E; (2016) Polycyclic Aromatic Hydrocarbons and Selected Heavy Metals in Some Oil Polluted Sites in Delta State, Nigeria. JEP, 7: 1389-1410.

Sabo, A; Ladan, M; (2018) Phytoremediation Potential of Some Indigenous Herbaceous Plant Species Growing on Metalliferous Mining Sites At Nahuta, Bauchi State, Nigeria. IOSR-JESTFT, 12: 41-46.

Tanhan, P; Pokethitiyook, P; Kruatrachue, M; Chaiyarat; R; Upatham, S (2011). Effects of soil amendments and EDTA on lead uptake by Chromolaena odorata: greenhouse and field trial experiments. Int.. J. Phytorem. 13(9):897-911

Wang, J; Liu, X; Zhang, X; Wang, Z; Cao, Z; Zhong, C; $\mathrm{Su}, \mathrm{P}$ (2010) Phytoremediation potential of Cyperus rotundus for diesel-contaminated wetland. J Shanghai Univ (English Edition), 14(5): 326-331.

Basumatary, B; Saikia, R; Chandra, DH; Bordoloi, S (2013) Field Note: Phytoremediation of Petroleum Sludge Contaminated Field Using Sedge Species,Cyperus Rotundus(Linn.) and Cyperus Brevifolius(Rottb.) Hassk. Int. J. Phytorem, 15(9): 877-888.

Suman, J; Uhlik, O; Viktorova, J; Macek, T (2018) Phytoextraction of Heavy Metals: A Promising Tool for Clean-Up of Polluted Environment? Front. Plant Sci., 9:1476.

Odukoya, J; Lambert, R; Sakrabani, R (2019). Understanding the Impacts of Crude Oil on Induced
Abiotic Stresses on Agrifood production: A Review. Horticulturae: 5, 47

Wilberforce, OJO (2016). Profile of Heavy Metals in Crude Oil Commonly Consumed for Medicinal Purposes in Abakaliki. IOSR J Pharm Biol Sci, 11(3): 43-44

Tokalioglu, S; Kartal, S; Gultekin, A (2006). Investigation of Heavy Metal Uptake by Vegetables Growing in Contaminated Soils Using the Modified BCR Sequential Extraction Method. Int. J. Environ. Anal. Chem., 86(6):417-430

USDA (2011) Soil Quality Kit- Guides for Educators. USDA Natural Resources Conservation Service. Retrieved from https://www.nrcs.usda.gov/wps/portal/nrcs/main/soils/ health/resource/

Messsou, A; Coulibaly, L; Doumbia, L; and Gourene, G (2013) Plants diversity and phytoaccumulators identification on the Akouedo landfill ( Abidjan, Cote d'Ivoire). Afr. J. Biotechnol, 12(3) : 253-264

. Nwaichi, E. O. and Chuku, L. C. (2018). Biological Soil Quality Indicators and Conditioners in a Plant-Assisted Remediation of Crude Oil Polluted Farmland. JEP, 8: 1622-1635.

Garba, ST; Gudusu, M; Inuwa, LB (2018). Accumulation Ability of the Native Grass Species, Cyperus rotundus for the Heavy Metals; Zinc(zn), Cadmium(Cd), Nickl( $\mathrm{Ni})$ and Lead(Pb). Int Res J Pure Appl Chem, 17(1): 115

Vinje, E (2014) Using autumn's bounty. Planet Natural Research Centre, US. Retrieved 20 December 2019 from https://www.planetnatural.com/leaf-mold

HSE-ENV (2004). Accompanying guidelines for SPDC EIA process-Data Collection. Vol 111.HSE-ENV, SPDC 2004- 0002712

DPR (2018). Environmental Guidelines and Standards for the Petroleumn Industry in Nigeria. Department of Petroleumn Resources (DPR), Victoria Island Lagos, Nigeria.

Singh, J; Kalamdhad, AS (2011) Effects of Heavy Metals on Soil, Plants, Human Health and Acquatic life. IJRCE, 1(2): $15-21$

Osuoha, J.O. and Nwaichi, E.O. (2020). Enzymatic technologies as green and sustainable techniques for remediation of oil-contaminated environment: state of the art. Int. J. Environ. Sci. Technol.. https://doi.org/10.1007/s13762-020-02876-w 